\title{
Kesadaran Berhenti Merokok Masyarakat di Wilayah Kerja Puskesmas Penawar Jaya Kabupaten Tulang Bawang Tahun 2020
}

\section{Awareness of Quitting Smoking Community in the Working Area of Puskesmas Penawar Jaya Tulang Bawang District in 2020}

\author{
Puspa Sari $^{1}$, Lolita Sary ${ }^{2}$, Christin Angelina Febriani ${ }^{2}$ \\ ${ }^{1}$ Puskesmas Penawar Jaya, Penawar Rejo, Banjar Margo, Kabupaten \\ Tulangbawang, Lampung, Indonesia \\ 2Program Studi Kesehatan Masyarakat, Fakultas Kesehatan Masyarakat, \\ Universitas Malahayati Bandar Lampung, Lampung, Indonesia
}

Korespondensi Author: puspa4314@gmail.com

Penyerahan: 23-11-2020, Perbaikan: 03-12-2020, Diterima: 23-01-2021

\begin{abstract}
Non-Communicable Diseases is the leading cause of death worldwide. The purpose of this study was to determine the awareness of stop smoking in the working area of the UPTD Puskesmas Penawar Jaya, Tulang Bawang Regency. The type of research used is qualitative with a phenomenological approach. The subjects in this study were people who had stop smoking in the working area of the Penawar Jaya Community Health Center, Tulang Bawang Regency. This informant consists of 4 people, namely 1 person as the key informant and 3 people as informants. Data collection techniques using indepth interviews. The results of this study indicate that all informants said that awareness of quitting smoking was initiated because they suffered from a risky disease. The benefits of quitting smoking are that the body feels healthy and reducing expenses. How to overcome community barier in quitting smoking can be overcome by providing counseling. It is hoped that the primary health care will continue to provide support to people who are trying to stop smoking.
\end{abstract}

Keyword: awareness, benefits, barier, efforts to stop smoking

\section{ABSTRAK}

Penyakit Tidak Menular (PTM) menjadi penyebab kematian terbanyak di seluruh dunia. Hampir 6 juta kematian per tahun disebabkan karena menghisap tembakau. Tujuan penelitian ini untuk mengetahui mengetahui kesadaran berhenti merokok masyarakat di wilayah kerja UPTD Puskesmas Penawar Jaya Kabupaten Tulang Bawang. Jenis penelitian yang digunakan adalah kualitatif dengan pendekatan fenomenologi. Subyek dalam penelitian ini adalah masyarakat yang sudah berhenti merokok di wilayah kerja UPTD Puskesmas Penawar Jaya Kabupaten Tulang Bawang. informan ini terdiri dari 4 orang yaitu 1 orang sebagai informan kunci dan 3 orang sebagai informan. Teknik pengumpulan data menggunakan wawancara mendalam. Hasil penelitian ini menunjukkan bahwa semua informan mengatakan kesadaran berhenti merokok diawali karena menderita penyakit beresiko. Manfaat berhenti merokok adalah badan terasa sehat dan mengurangi pengeluaran. Sebagian kecil informan mengatakan bahwa hambatan berhenti merokok yaitu badan terasa lemas. Cara mengatasi hambatan masyarakat dalam berhenti merokok dengan memberikan konseling. Diharapkan pihak puskesmas dapat terus melakukan dukungan kepada masyarakat yang berupaya berhenti merokok.

Kata Kunci: Kesadaran, manfaat, hambatan, upaya berhenti merokok (UBM) 


\section{PENDAHULUAN}

Penyakit Tidak Menular (PTM) menjadi penyebab kematian terbanyak di seluruh dunia. Penyakit Tidak Menular (PTM) umumnya dikenal sebagai penyakit kronis yang berhubungan dengan gaya hidup (Kemenkes, 2017). Dari 10 PTM penyebab kematian utama di Indonesia, 6 diantaranya adalah stroke $21,1 \%$, penyakit jantung koroner $12,9 \%$, diabetes mellitus dengan komplikasi 6,7\%, tuberkulosis paru 5,7\%, hipertensi dengan komplikasi $5,3 \%$, penyakit paru obstruksi kronis 4,9\%, yang di sebabkan oleh faktor risiko perilaku merokok (Direktorat P2PTM Indonesia, 2019). Perilaku merokok disebut sebagai suatu kebiasaan atau ketagihan, selain karena zat di dalamnya yang dapat menimbulkan adiksi atau ketagihan, juga karena penggunaan tembakau secara menetap dan berulang-ulang. Perilaku merokok juga dipengaruhi oleh keterpaparan media atau pengaruh iklan tentang rokok, kemudahan mendapatkan rokok, pengaruh orang tua, dan pengaruh teman sebaya (Setyawati, 2017).

Menurut Badan Kesehatan Dunia World Health Organization (WHO), hampir 6 juta kematian per tahun disebabkan karena menghisap tembakau. Angka ini diperkirakan akan meningkat menjadi lebih dari 8 juta kematian di tahun 2030. Indonesia menduduki peringkat ke 4 dunia sebagai pengonsumsi rokok tertinggi dengan jumlah perokok aktif mencapai 65,2 juta jiwa. Terdiri dari 52,9\% laki-laki dewasa, dan $12,3 \%$ perempuan dewasa (WHO, 2018). Sebagai salah satu negara penyumbang asap rokok terbesar di Asia Tenggara, Pemerintah Indonesia melakukan upaya penanggulangan perilaku merokok. Pemerintah membuat kebijakan dan strategi pengendalian terhadap konsumsi produk tembakau, antara lain; monitoring konsumsi produk tembakau, perlindungan terhadap paparan asap rokok, upaya pelayanan berhenti merokok, peningkatan kewaspadaan masyarakat akan bahaya produk tembakau, eliminasi iklan, promosi dan sponsor produk tembakau, dan menurunkan akses terhadap produk tembakau (Riskesdas, 2013). Selain itu juga, pemerintah menetapkan landasan hukum pengendalian dampak rokok terhadap kesehatan, antara lain; UU No.36/ 2009 tentang Kesehatan, PP No. 109 / 2012 tentang Pengamanan Bahan yang Mengandung Zat Adiktif Berupa Produk Tembakau bagi Kesehatan, Permenkes No. 40/ 2013 tentang Peta Jalan Pengendalian Dampak Konsumsi Rokok Bagi Kesehatan, Permenkes No. 28/ 2013 tentang Pencantuman Peringatan Kesehatan dan Informasi Kesehatan pada Kemasan Produk Tembakau.

Menurut hasil Riset Kesehatan Dasar (Riskesdas) tahun 2013 Provinsi Lampung menduduki peringkat ke- 6 dengan prevalensi merokok penduduk umur lebih dari sama dengan 10 tahun. Provinsi tertinggi ada di Provinsi Kepulauan Riau 27,2\%, Provinsi Jawab Barat dan Provinsi Bengkulu 27,1\%, Provinsi NTB dan Provinsi Gorontalo 26,8\% dan Provinsi Lampung 26,5\%. Sedangkan tahun 2018, Provinsi Lampung menduduki peringkat ke-3 dengan prevalensi merokok penduduk umur lebih dari sama dengan 10 tahun. Prevalensi tertinggi ada di Provinsi Jawa Barat $29,3 \%$, Gorontalo 29,2\%, dan Lampung 29,00\% (Riskesdas, 2018). Pemerintah Provinsi Lampung melaksanakan upaya penaggulangan perilaku merokok, antara lain menetapkan Peraturan Gubernur No. 02 Tahun 2014 tentang Kawasan Tanpa asap Rokok, melaksanakan 
peningkatan kapasitas teknis petugas kesehatan dalam layananan Upaya Berhenti Merokok (UBM), dan sudah ada beberapa puskesmas di Provinsi Lampung yang melaksanakan UBM dengan menggunakan smoke analyzer untuk mengetahui kadar atau kandungan karbon monoksida (CO) pada pasien yang ingin berhenti merokok.

Prevalensi perilaku merokok di Kabupaten Tulang Bawang pada tahun 2017 pada umur lebih dari sama dengan 10 tahun didapatkan 27,3\%, tahun 2018 pada umur lebih dari sama dengan 10 tahun didapatkan $28,1 \%$, dan pada tahun 2019 didapatkan 30,4\% penduduk dengna umur lebih dari sama dengan 10 tahun yang memiliki perilaku merokok (Dinas Kesehatan Tulang Bawang, 2019). Berhenti merokok bukanlah hal yang mudah untuk dilakukan oleh orang yang memiliki perilaku merokok. Menurut hasil survei yang dilakukan oleh Lembaga Menanggulangi Masalah Merokok (LM3) dari 375 responden, dinyatakan $66,2 \%$ perokok pernah mencoba berhenti merokok, tetapi mereka gagal. Kegagalan ini disebabkan oleh beberapa macam; $42,9 \%$ tidak tahu caranya; 25,7\% sulit berkonsentrasi dan 2,9\% terikat oleh sponsor rokok. Sementara itu, ada yang berhasil berhenti merokok disebabkan kesadaran sendiri (76\%), sakit $(16 \%)$, dan tuntutan profesi (8\%) (Fawzani \& Triratnawati, 2015).

Merokok merupakan perilaku yang salah satunya dipengaruhi oleh persepsi dan kepercayaan individu. Pengambilan keputusan untuk merubah perilaku merokok, dipengaruhi oleh hal-hal berikut yang disebutkan dalam teori Health Belief Model (HBM) antara lain; persepsi tentang kerentanan terhadap penyakit (perceived susceptibility), potensi ancaman (perceived savety), manfaat yang dirasakan jika mengadopsi prilaku yang ditawarkan (perceived benefit), hambatan yang dirasakan (perceived barrier), dan isyarat untuk bertindak (cues to action). Model teori ini merupakan formulasi konseptual untuk mengetahui persepsi individu apakah mereka menerima atau tidak tentang kesehatan mereka, keinginan individu untuk menghindari kesakitan, dan kepercayaan mereka bahwa terdapat usaha untuk menghindari penyakit tersebut (Priyoto, 2018). Kabupaten Tulang Bawang telah melaksanakan Pendataan Keluarga Sehat dalam Program Indonesia Sehat melalui Pendekatan Keluarga (PIS-PK) pada tahun 2018. Menurut data yang diperoleh, sebanyak $72 \%$ anggota keluarga masih merokok. Pemerintah Kabupaten Tulang Bawang melakukan upaya penanggulangan perilaku merokok di masyarakat, dengan menetapkan Peraturan Daerah Nomor 06 tahun 2019 tentang pemberlakuan Kawasan Tanpa asap Rokok (KTR), sosialisasi KTR oleh Dinas Kesehatan Kabupaten, mengirim tenaga kesehatan dalam rangka bimbingan teknis UBM ke Dinas Kesehatan Provinsi, dan sosialisasi program UBM ke 18 UPTD Puskesmas yang berada di Kabupaten Tulang Bawang (Dinas Kesehatan Kabupaten Tulang Bawang, 2018). Hasil pendataan PIS-PK di UPTD Puskesmas Penawar Jaya tahun 2017 terdapat 63,2\% anggota keluarga masih merokok, tahun 2018 menyebutkan sebanyak $68,71 \%$ anggota keluarga masih merokok, dan tahun 2019 didapatkan 69,83\% anggota keluarga masih merokok. Upaya Berhenti Merokok (UBM) terus dilakukan sebagai upaya tindak lanjut dalam menurunkan angka merokok di wilayah kerja UPTD Puskesmas Penawar Jaya. Pemegang 
program PTM di Puskesmas melakukan berbagai inovasi, mulai dari sosialisai Perda tentang pemberlakuan KTR, penyuluhan tentang bahaya merokok, sampai menyediakan ruang konseling bagi masyarakat yang ingin berhenti merokok (Data Sekunder Puskesmas Penawar Jaya, 2018).

\section{METODE}

Penelitian ini adalah penelitian kualitatif dengan pendekatan phenamenology. Subyek yang diteliti adalah masyarakat perokok aktif yang berjumlah 3 orang dan petugas kesehatan pemegang program PTM berjumlah 1 orang. Objek yang diteliti yaitu kesadaran berhenti merokok. Teknik analisis data dalam penelitian ini menggunakan triangulasi sumber dan triangulasi metode.

\section{HASIL PENELITIAN \\ Latar Belakang Merokok}

Berdasarkan hasil penelitian yang dilakukan melalui wawancara mendalam mengenai latar belakang informan dalam berhenti merokok, didapatkan seluruh informan mulai mengenal rokok sejak remaja. Seperti pernyataan informan berikut:

"...kenal rokok yaitu saat SMA karena ikut-ikutan teman"

(Tn. W 33 tahun)

"...kenal rokok saat remaja, berawal dari coba-coba hingga menjadi kecanduan" (Tn. S 51 tahun)

"...kenal rokok saat SMP"

(Tn. P 43 tahun)

Dari hasil wawancara diatas didapatkan bahwa informan 1 ( $\mathrm{Tn}$. W) mengatakan mengenal rokok yaitu saat SMA karena mengikuti teman, informan 2 (Tn. S) mengatakan bahwa mengenal rokok saat remaja yang berawal dari cobacoba hingga menjadi kecanduan, dan informan 3 (Tn. P) mengatakan bahwa mengenal rokok saat SMA.

Sedangkan jumlah rokok yang dikonsumsi dalam sehari adalah sebagai berikut:

"...7-8 batang" (Tn. W 33 tahun)

"...10-11 batang" (Tn. S 51 tahun)

"...9-10 batang" (Tn. P 43 tahun)

Berdasarkan hasil wawancara diatas maka dapat disimpulkan bahwa sebagian besar informan rata-rata menghabiskan rokok 8-9 batang perhari.

\section{Kesadaran Berhenti Merokok}

Pengaruh kebiasaan merokok terhadap perilaku sehari-hari yaitu berdampak pada kesehatan.

"...merasa sesak nafas, suara serak, batuk-batuk, dan nyeri di area leher"

(Tn. W 33 tahun)

"...merasa sesak nafas dan batukbatuk" (Tn. S 51 tahun)

"...sangat merugikan kesehatan" (Tn. P 43 tahun)

Berdasarkan hasil wawancara mendalam diatas maka didapatkan bahwa informan 1 (Tn. W) mengatakan merokok dapat menyebabkan sesak nafas, suara serak, batuk-batuk, dan nyeri di area leher, informan 2 (Tn. S) mengatakan merokok dapat menyebabkan sesak nafas dan batuk-batuk, dan informan 3 (Tn. P) mengatakan merokok sangat merugikan kesehatan. Berdasarkan hasil wawancara kepada 3 orang informan utama didapatkan bahwa alasan mereka berhenti merokok yaitu karena divonis dokter mengalami penyakit berisiko.

"...saya berhenti merokok karena divonis dokter mengalami gondok beracun" (Tn. W 33 tahun)

"...saya mengalami penyakit hipertensi dan jantung sehingga 
disarankan dokter untuk berhenti merokok" (Tn. S 51 tahun)

"...saya sangat menderita akibat merokok, selain itu saya menderita penyakit PPOK" (Tn. P 43 tahun)

Berdasarkan hasil wawancara diatas maka didapatkan bahwa informan 1 ( $\mathrm{Tn}$. W) mengatakan bahwa berhenti merokok karena divonis dokter mengalami penyakit gondok beracun, informan 2 (Tn. S) mengatakan bahwa berhenti merokok karena mengalami penyakit hipertensi dan jantung sehingga disarankan dokter untuk berhenti merokok, dan informan 3 (Tn. P) mengatakan bahwa berhenti merokok karena menderita akibat merokok dan mengalami penyakit PPOK.

\section{Manfaat Berhenti Merokok}

Berdasarkan hasil penelitian yang dilakukan melalui wawancara mendalam mengenai manfaat berhenti merokok, diketahui dari 3 responden didapatkan bahwa:

"...agar tidak menderita penyakit berbahaya seperti kanker, stroke dan lain-lain" (Tn. W 33 tahun) "....agar tidak menderita penyakit beresiko" (Tn. P 51 tahun)

Kemudian dari 3 informan didapatkan bahwa seluruh informan mengatakan manfaat yang diperoleh apa bila seseorang berhenti merokok yaitu badan terasa lebih sehat dan 2 informan mengatakan manfaat berhenti merokok yaitu dapat mengurangi pengeluaran sehingga dapat menabung.

\footnotetext{
"...terasa lebih sehat serta mengurangi pengeluaran" (Tn. W 33 tahun)

"...tidak mengalami sesak napas dan batuk-batuk, selain itu dapat menabung" (Tn. S 51 tahun)

"...badan terasa sehat" (Tn. P 43 tahun)
}

Sedangkan menurut 3 informan yang dapat merasakan manfaat dari upaya berhenti merokok adalah diri sendiri dan keluarga.

$$
\begin{aligned}
& \text { "...diri sendiri, keluarga, serta } \\
& \text { orang terdekat saya" (Tn. W } 33 \\
& \text { tahun) } \\
& \text { "...diri sendiri" (Tn. S } 51 \text { tahun) } \\
& \text { "...diri sendiri dan keluarga" (Tn. } \\
& \text { P } 43 \text { tahun) }
\end{aligned}
$$

Berdasarkan hasil wawancara didapatkan bahwa semua informan mengatakan manfaat dari berhenti merokok yaitu terhindar dari penyakit-penyakit beresiko, selain itu dapat mengurangi pengeluaran yang akhirnya bisa menabung. Seluruh informan juga mengatakan bahwa yang dapat merasakan manfaat dari upaya berhenti merokok adalah diri sendiri dan keluarga.

\section{Hambatan yang Dihadapi Dalam Upaya Berhenti Merokok}

Menurut ketiga informan didapatkan bahwa jika sehari saja tidak merokok maka akan menyebabkan:

"...emosi tidak stabil, merasa ngantuk dan lesu" (Tn. W 33 tahun)

"...badan terasa lemas dan mulut terasa masam" (Tn. S 51 tahun)

"...mulut terasa masam dan mudah ngantuk" (Tn. P 43 tahun)

Berdasarkan hasil wawancara diatas maka didapatkan bahwa informan 1 ( $\mathrm{Tn}$. W) mengatakan bahwa jika sehari tidak merokok maka akan menyebabkan emosi tidak stabil, merasa ngantuk dan lesu, informan 2 (Tn. S) mengatakan jika sehari tidak merokok akan menyebabkan badan terasa lemas dan mulut terasa masam, dan informan 3 (Tn. P) mengatakan bahwa jika sehari saja tidak merokok 
akan menyebabkan mulut terasa masam dan mudah mengantuk. Berdasarkan hasil wawancara kepada infoman kunci didapatkan bahwa masyarakat yang berupaya berhenti merokok disebabkan karena divonis dokter mengalami penyakitpenyakit yang beresiko.

"...Ada beberapa masyarakat
yang berupaya untuk berhenti
merokok karena telah divonis
dokter mengalami penyakit yang
parah seperti hipertiroid, jantung,
hipertensi dan lain-lain" (Tn. R 33
tahun)

Berdasarkan hasil wawancara didapatkan bahwa cara supaya berkomitmen untuk berhenti merokok yaitu dengan diniatkan untuk berhenti merokok demi kesahatan pribadi dan keluarga dan menjaga jarak dengan orang-orang yang merokok. Seperti pernyataan informan berikut:

"...untuk berhenti merokok demi kesehatan pribadi dan keluarga" (Tn. W 33 tahun)

"...menjaga jarak dengan orangorang yang merokok" (Tn. S 51 tahun)

"...menjauhi rokok" (Tn. P 43 tahun)

Seluruh informan mengatakan ada kesulitan saat berupaya berhenti merokok.

$$
\begin{aligned}
& \text { "...iya, terutama setelah makan } \\
& \text { seperti ada yang kurang" (Tn. W } \\
& 33 \text { tahun) } \\
& \text { "...pasti, awalnya badan terasa } \\
& \text { lemas" (Tn. } 51 \text { tahun) } \\
& \text { "...ya" (Tn. P } 43 \text { tahun) }
\end{aligned}
$$

Sedangkan menurut informan kunci cara untuk mengatasi hambatan masyarakat dalam berupaya berhenti merokok yaitu dengan memberikan konseling kepada masyarakat.

"...memberikan penyuluhan kepada masyarakat bahaya merokok untuk kesehatan" (Tn. R 43 tahun)
Berdasarkan hasil wawancara didapatkan seluruh informan mengatakan bahwa reaksi tubuh yang dirasakan ketika sudah mencoba menghentikan perilaku merokok adalah merasa lemas namun setelah biasa badan terasa sehat.

"...awal terasa lemas dan ngantuk hingga sakit kepala" (Tn. W 33 tahun)

"...lemas dan berat namun lamalama badan terasa sehat" (Tn. S 51 tahun)

"...badan lebih sehat" (Tn. P 43 tahun)

Berdasarkan hasil wawancara terhadap informan kunci didapatkan bahwa masyarakat yang berhenti merokok sebagian besar karena divonis dokter mengalami penyakit yang beresiko sehingga disarankan untuk berhenti merokok.

\section{Upaya yang Dilakukan Dalam Berhenti Merokok}

Berdasarkan hasil wawancara terhadap 3 informan utama didapatkan bahwa sudah ada yang menyampaikan informasi tentang Program Upaya Berhenti Merokok (UBM). Seperti pernyataan informan berikut:

$$
\begin{aligned}
& \text { "...iya ada" (Tn. W } 33 \text { tahun) } \\
& \text { "...ada" (Tn. S } 51 \text { tahun) } \\
& \text { "... ada, petugas dari Puskesmas } \\
& \text { Penawar Jaya" (Tn. P } 43 \text { tahun) }
\end{aligned}
$$

Sesuai dengan hasil wawancara terhadap informan kunci yang menyatakan bahwa sebagai pemegang program dalam hal upaya berhenti merokok masyarakat di wilayah kerja UPTD Puskesmas Penawar Jaya yaitu member dukungan kepada masyarakat yang berupaya berhenti merokok, dengan cara memberikan penyuluhan kepada masyarakat yang bersangkutan. 
"Mendukung masyarakat yang berupaya berhenti merokok, dengan cara memberikan penyuluhan kepada masyarakat yang bersangkutan" (Tn. R 33 tahun)

Cara agar informan tetap konsisten untuk berhenti merokok yaitu dengan cara:

"Saya konsisten untuk berhenti merokok karena saya berpikir bahwa jika saya terus merokok maka saya akan mengalami sakit yang lebih parah dan tidak bisa bekerja, dan jika saya tidak bekerja maka anak-anak saya akan terlantar" (Tn. W 33 tahun)

"Saya berhenti merokok karena saya ingin memiliki keluarga yang sehat dan mereka terhindar dari bahaya asap rokok yang mereka hisap" (Tn. S 51 tahun)

"Saya berkomitmen untuk berhenti merokok karena saya ingin melindungi keluarga yang saya cintai. Jika saya terus merokok maka penyakit kronis yang saya derita akan semakin parah dan dapat menyebabkan meninggal dunia" (Tn. P 43 tahun)

Dari hasil wawancara diatas didapatkan bahwa informan 1 ( $\mathrm{Tn}$. W) mengatakan bahwa cara menjaga agar tetap konsisten berhenti merokok adalah dengan berpikir bahwa jika terus merokok maka akan mengalami sakit yang lebih parah dan tidak bisa bekerja, dan jika ia tidak bekerja maka anakanaknya akan terlantar, informan 2 (Tn. S) mengatakan berhenti merokok karena ia ingin memiliki keluarga yang sehat dan keluarganya terhindar dari bahaya asap rokok yang mereka hisap, sedangkan informan 3 (Tn. P) mengatakan bahwa berkomitmen untuk berhenti merokok karena ia ingin melindungi keluarga yang dicintai. Jika ia terus merokok maka penyakit kronis yang diderita akan semakin parah dan dapat menyebabkan meninggal dunia. Adapun hasil wawancara terhadap ketiga informan utama didapatkan bahwa reaksi anggota keluarga ketika mereka memutuskan untuk berhenti merokok adalah senang dan sangat mendukung.

$$
\begin{aligned}
& \text { "...senang dan sangat } \\
& \text { mendukung" (Tn. W } 33 \text { tahun) } \\
& \text { "...sangat senang" (Tn. S } 51 \\
& \text { tahun) } \\
& \text { "...senang sekali dan sangat } \\
& \text { mendukung" (Tn. P } 43 \text { tahun) }
\end{aligned}
$$

Menurut hasil wawancara kepada informan kunci didapatkan bahwa upaya yang dilakukan untuk menjaga agar masyarakat tetap berhenti merokok yaitu mengajarkan kepada masyarakat yang berupaya berhenti merokok untuk beralih pada produk pengganti nikotin, pengelolaan stress, menganjurkan untuk menjauhkan diri dari lingkungan perokok, serta memberikan terapi dan konseling perilaku. Selain itu informan kunci juga menyampaikan informasi tentang manfaat berhenti merokok yaitu mengurangi risiko penyakit pada tubuh seperti jantung coroner, infeksi saluran pernafasan, risiko stroke, risiko kanker dan lain-lain.

\section{PEMBAHASAN}

\section{Kesadaran Berhenti Merokok}

Berdasarkan hasil wawancara didapatkan bahwa informan 1 ( $\mathrm{Tn}$. W) mengatakan merokok dapat membuat lebih semangat dan menghilangkan rasa jenuh, informan 2 (Tn. S) mengatakan merokok dapat menyebabkan sesak nafas dan batuk-batuk, dan informan 3 (Tn. P) mengatakan merokok sangat merugikan kesehatan. Dalam hal ini dampak yang dirasakan informan saat merokok yaitu menderita penyakit beresiko. Seperti halnya 
informan 1 (Tn. W) mengatakan bahwa berhenti merokok karena divonis dokter mengalami penyakit gondok beracun, informan 2 (Tn. S) mengatakan bahwa berhenti merokok karena mengalami penyakit hipertensi dan jantung sehingga disarankan dokter untuk berhenti merokok, dan informan 3 (Tn. P) mengatakan bahwa berhenti merokok karena menderita akibat merokok dan mengalami penyakit PPOK.

Didukung oleh penelitian Nancy (2018) yang menyatakan bahwa orang yang berhenti merokok lebih lama hidupnya dari pada orang yang terus merokok. Orang yang berhenti merokok sebelum berumur 50 tahun mempunyai setengah risiko kematian pada 15 tahun yang akan datang dibandingkan dengan orang yang masih terus merokok. Berhenti merokok menambah harapan hidup sebab keadaan ini mengurangi risiko kematian yang disebabkan penyakit yang berhubungan dengan rokok. Salah satu diantaranya adalah kanker paru, penyebab utama yang tersering dari kematian karena kanker baik pada laki-laki maupun perempuan. Risiko kematian kanker paru 22 kali lebih tinggi pada lakilaki perokok, dan 12 kali lebih tinggi pada perempuan perokok dibandingkan dengan orang-orang yang tidak merokok. Merokok merupakan penyebab utama penyakit PPOK. Merokok meningkatkan risiko PPOK dengan mempercepat penurunan fungsi paru sesuai dengan pertambahan usia. Penelitian ini sejalan dengan penelitian Fawzani (2018) yang menyatakan bahwa berhenti merokok menyebabkan mereka bertambah tahu apa itu bahaya rokok. Adanya pengetahuan bahaya merokok yang disebarluaskan baik oleh pemerintah maupun LSM anti rokok diharapkan para perokok juga ada keinginan (niat) untuk berhenti merokok, sehingga kerugian yang dialami oleh perokok pasif akan terlindungi.

Alasan utama perokok untuk berhenti merokok adalah keinginan seorang perokok untuk hidup dengan gaya hidup sehat. Tidak semua perokok memilih cara yang sama untuk berhenti merokok, namun berbeda-beda sesuai dengan keinginan dan kemampuannya untuk melalui proses berhenti merokok. Alasan kedua berhenti merokok adalah factor biaya (Ardini, 2017).

\section{Manfaat Berhenti Merokok}

Upaya berhenti merokok merupakan kegiatan yang diprogramkan untuk dilaksanakan di puskesmas dalam bentuk promosi kesehatan pada masyarakat yang melibatkan pengelola program, dokter puskesmas, dan fungsional promosi kesehatan. Kegiatan ini merupakan bentuk promosi kesehatan yang dilakukan puskesmas (Ditjen P2PTM Dirjen P2P Kemenkes RI, 2017). Berdasarkan hasil wawancara didapatkan bahwa semua informan mengatakan manfaat dari berhenti merokok yaitu terhindar dari penyakit-penyakit berisiko seperti jantung, hipertensi, PPOK dan lain-lain. selain itu dapat mengurangi pengeluaran yang biasanya untuk beli rokok, namun saat sudah berhenti merokok dapat digunakan untuk keperluan lain dan bisa menabung. Seluruh informan juga mengatakan bahwa yang dapat merasakan manfaat dari upaya berhenti merokok adalah diri sendiri dan keluarga. Hal ini karena asap rokok dapat menyebabkan penyakit bagi lingkungan keluarga.

Sejalan dengan penelitian Esti (2018) yang menyatakan bahwa semakin rendah pengeluaran seseorang untuk merokok dan semakin sedikit jumlah pemakaian 
rokok per hari, maka semakin tinggi motivasi berhenti merokok. Menurut analisa peneliti manfaat berhenti merokok dapat membuah tubuh lebih sehat dan dapat mengurangi resiko terhindarnya dari penyakitpenyakit berbahaya. Selain itu orang yang berhenti merokok juga dapat memperpanjang masa hidup dibandingkan dengan orang yang masih merokok aktif. Untuk mendukung masyarakat yang berhenti merokok, petugas kesehatan dapat rutin untuk melakukan penyuluhan kepada masyarakat mengenai manfaat berhenti merokok yaitu dapat memperpanjang masa hidup juga untuk menghindari penyakit beresiko yang disebabkan oleh rokok.

\section{Hambatan yang Dihadapi Dalam Upaya Berhenti Merokok}

Berdasarkan hasil wawancara didapatkan bahwa seluruh informan mengatakan ada kesulitan saat berupaya berhenti merokok yaitu badan terasa lemas, emosi tidak stabil, rasa mengantuk berkepanjangan dan lain-lain. Hal ini disebabkan oleh kecanduan perokok aktif terhadap rokok, sehingga saat pertama mencoba untuk berhenti merokok dapat menyebabkan psikis yang tidak stabil. Selain itu informan mengatakan bahwa hambatan yang dirasakan yaitu teman-teman yang masih merokok. Seseorang yang berupaya untuk berhenti merokok namun masih sering melakukan pertemuan dengan orang-orang perokok aktif akan beresiko untuk merokok kembali. Sedangkan menurut informan kunci cara untuk mengatasi hambatan masyarakat dalam berupaya berhenti merokok yaitu dengan memberikan konseling kepada masyarakat. Konseling kepada masyarakat ini meliputi mengajarkan terapi untuk perokok aktif yang berupaya berhenti merokok, memberikan penjelasan bahaya berhenti merokok, serta memberikan dukungan agar bisa berhenti merokok.

Sejalan dengan penelitian Jusuf (2018) bahwa menghentikan perilaku merokok itu sulit karena saat perokok mencoba berhenti, kondisi yang mereka rasakan semakin buruk. Secara psikologis upaya berhenti merokok menjadi sulit karena adanya pengaruh lingkungan sosial, kebiasaan mengkonsumsi rokok, kemudahan akses terhadap rokok, ketiadaan aturan membatasi usia perokok, dan pengaruh teman sebaya. Bagitu pula menurut Sani, faktor penyulit seseorang berhenti merokok adalah efek psikoaktif nikotin dan kemudahan mendapatkan rokok. Sejalan dengan penelitian Meta (2019) yang menyatakan bahwa para informan takut dengan isi pesan pada layanan public iklan (ILM) tentang bahaya merokok. Ini bisa dilihat dari wawancara kutipan dari jawaban informan. Informan melihat ILM tentang bahaya merokok disiarkan di televisi. Dalam penelitian ini, hampir semua informan mengatakan bahwa pertama informan mulai mencoba merokok karena ada perasaan tidak aman jika tidak merokok sambil berkumpul dengan teman-teman di lingkungan. Ada juga informan yang merokok karena penasaran, jadi niatnya adalah mencoba merokok. Bahkan informan yang mengatakan bahwa salah satu faktor yang membuat informan penasaran dan ingin mencoba rokok itu karena informan melihat orang tua informan yang merokok di rumah. Perokok aktif berusaha merokok karena ada pengaruh dari faktor keluarga dan faktor lingkungan tempat mereka tinggal. Berdasarkan penelitian ini, diharapkan lingkungan dapat 
membantu perokok aktif tidak lagi bergantung pada rokok.

Hambatan terbesar untuk berhenti merokok pada penelitian ini dikarenakan sebagian besar remaja mempunyai teman yang perokok juga, sesuai yang tertuang pada salah satu poin pernyataan pada kuesioner. Semakin rendah control diri remaja maka semakin tinggi perilaku merokok remaja. Salah satu yang mempengaruhi control diri remaja adalah teman sebaya. Jika sebagian besar teman sebaya remaja adalah perokok, maka kemungkinan remaja tersebut merokok adalah besar (Marsiana, 2017). Didukung oleh penelitian Rabiatul (2018) yang menyatakan bahwa efikasi diri yang dilakukan informan dalam menjauhi rokok yaitu menjauhi pergaulan dengan teman sesama perokok aktif dan hambatan yang dirasakan informan yaitu karena informan sulit mengontrol perilaku merokonya akibat lingkungan informan yang merupakan perokok aktif. Dapat disimpulkan bahwa efikasi diri atau kemampuan awal informan awalnya sangat kecil namun setelah informan terdiagnosis penyakit informan berhasil meningkatkan efikasi dirinya.

\section{Upaya yang Dilakukan Untuk Berhenti Merokok}

Hasil wawancara terhadap 3 informan utama didapatkan bahwa sudah ada yang menyampaikan informasi tentang Program Upaya Berhenti Merokok (UBM) yang meliputi cara berhenti merokok, dampak merokok, serta terapi yang dapat digunakan dalam proses berhenti merokok. Sedangkan menurut informan kunci juga ada kebijakan pemerintah terhadap upaya berhenti merokok masyarakat. Upaya Berhenti Merokok (UBM) merupakan program kesehatan yang dilandasi Peraturan Pemerintah No. 109 tahun 2012. Program ini merupakan fasilitas untuk masyarakat yang ingin berhenti dari kebiasaan tak sehat, dikembangkan agar bisa membantu masyarakat yang ingin berhenti merokok agar benar-benar bisa berhenti (Ditjen P2PTM Dirjen P2P Kemenkes RI, 2017). Dalam kehidupan sehari-hari setiap individu umumnya pernah mengalami peristiwa yang membuat terkejut yang akan membawa kehidupannya berbalik arah. Peristiwa tersebut bisa membuat individu mengalami kepasrahan yang dalam yang kemudian akan menjadi titik balik hidupnya menjadi lebih baik atau sebaliknya. Demikian juga dalam merokok, mantan perokok menyatakan bahwa ada pengalaman hidup yang membuatnya pasrah dan kemudian membulatkan tekadnya untuk berhenti merokok.

Setiap orang tentu memiliki alasan yang berbeda untuk berhenti merokok. Alasan tersebut sifatnya tidak tunggal, tetapi bisa ganda. Namun, ada alasan yang sifatnya utama serta ada alasan pendukung. Alasan gangguan kesehatan hamper merata ditemukan pada perokok yang ingin menghentikan kebiasaan merokoknya. Munculnya gangguan kesehatan seperti hipertensi, demam tinggi, batuk, dada nyeri dan sakit kepala (pusing tujuh keliling). Akibat gangguan kesehatan itu menyebabkan perokok merasakan lidah yang pahit dan rasa yang tidak enak setiap kali merokok (Nurhidayati, 2018).

Hasil wawancara terhadap informan kunci didapatkan bahwa upaya yang dilakukan untuk menjaga agar masyarakat tetap berhenti merokok yaitu mengajarkan kepada masyarakat yang berupaya berhenti merokok untuk beralih pada produk pengganti nikotin seperti 
nicotine patch, inhaler, tablet hisap, permen karet, dan semprotan hidung, pengelolaan stress, menganjurkan untuk menjauhkan diri dari lingkungan perokok, serta memberikan terapi dan konseling perilaku. Sejalan dengan hasil penelitian Oritasari (2019) mengatakan bahwa strategi klien dalam mengatasi adiksi nikotin dengan mengurangi jumlah rokok perharinya, menunda waktu merokok saat pagi hari, melaksanakan aktifitas fisik. Strategi klien dalam menangani efek putus nikotin sulit konsentrasi adalah dengan menyarankan untuk beristirahat sejenak dariaktifitasnya, mengkonsumsi makanan sehat seperti buah dan sayuran segar, strategi meningkatkan motivasi berhenti merokok harus ada keinginan yang kuat untuk berhenti merokok disamping itu perlu dukungan dari keluarga, teman dan petugas kesehatan untuk meningkatkan keberhasilan berhenti merokok.

Didukung oleh penelitian yang dilakukan oleh Wulandari (2019) yang menyatakan bahwa mayoritas responden pernah mencoba berhenti merokok dengan mengandalkan diri sendiri seperti: mengurangi jumlah konsumsi rokok, dan olahraga, selain itu banyak responden yang meminta bantuan kepada teman, dan orang tua dalam mendukung proses berhenti merokok, namun banyak dari responden yang mengalami kesulitan berhenti merokok dengan alasan perokok lainnya, dan adanya kegiatan. Sejalan dengan penelitian Fitri dkk (2017) yang menyatakan bahwa terapi pengganti nikotin relative lebih aman dibandingkan kandungan nikotin di dalam rokok sehingga pemberian dalam dosis besar dan jangka lama diperbolehkan. Sediaan yang tersedia antara lain ialah permen, permen karet, koyo, obat semprot, inhalasi, dan tablet. Penyerapan utama nikotin dalam sediaan nikotin pengganti adalah melalui mukosa mulut sehingga perokok tidak boleh menelan atau menghirup nikotin pengganti jika menjalani terapi pengganti nikotin.

Sedangkan menurut penelitian Sadono (2018) menyatakan bahwa masyarakat telah menyadari bahaya merokok dan mengetahui upaya yang bisa dilakukan untuk berhenti merokok. Selain itu, masyarakat juga memahami upaya berhenti merokok dan masyarakat dapat mengetahui kriteria tempat-tempat yang sesuai dengan Kawasan Tanpa Rokok dan Kawasan Terbatas Merokok. Selanjutnya, adanya deklarasi Kampung Tanpa Asap Rokok ini, masyarakat menjadi lebih sehat dan tidak ada asap rokok di Kampung Bulaksari RT 7 RW 6 tersebut, serta anak-anak tidak ada yang merokok lagi. Didukung oleh penelitian Yugistyowati (2018) yang menyatakan bahwa terdapat pengaruh signifikan terapi SEFT terhadap motivasi berhenti merokok pada remaja di Dusun Semampir Sedayu 2, Bantul, Yogyakarta didapatkan $P$ value $0,005(p>0,05)$. Kesimpulan penelitian ini adalah terapi SEFT dapat meningkatkan motivasi berhenti merokok pada remaja di Dusun Semampir Sedayu 2, Bantul, Yogyakarta.

\section{KESIMPULAN}

Informan mengatakan bahwa mereka berhenti merokok karena menderita penyakit beresiko dan dianjurkan oleh dokter untuk berhenti merokok. manfaat dari berhenti merokok, yaitu terhindar dari penyakit-penyakit berisiko, selain itu dapat mengurangi pengeluaran yang akhirnya bisa menabung. Ada kesulitan saat 
berupaya berhenti merokok, yaitu badan terasa lemas, emosi tidak stabil, rasa mengantuk berkepanjangan dan lain-lain. Sudah ada yang menyampaikan informasi tentang Program Upaya Berhenti Merokok (UBM). Program UBM dilakukan untuk menjaga agar masyarakat tetap berhenti merokok yaitu mengajarkan kepada masyarakat yang berupaya berhenti merokok untuk beralih pada produk pengganti nikotin, pengelolaan stress, menganjurkan untuk menjauhkan diri dari lingkungan perokok, serta memberikan terapi dan konseling perilaku.

\section{SARAN}

Diharapkan pihak puskesmas dapat terus melakukan dukungan kepada masyarakat yang berupaya berhenti merokok dan memperkuat Program Upaya Berhenti Merokok (UBM).

\section{DAFTAR PUSTAKA}

Amaliah, Rabiatul. (2018). Studi Analisis Tahap Pembentuk Efikasi Diri Dalam Upaya Berhenti Merokok Pada Klien Klinik Berhenti Merokok Di Balkesmas Wilayah Semarang. Al-Sihah : Public Health Science Journal Volume 10, Nomor 2, JuliDesember 2018

Ardini, Ratih Fatma. (2017). Proses Berhenti Merokok Secara Mandiri Pada Mantan Pecandu Rokok Dalam Usia Dewasa Awal. Jurnal Psikologi Pendidikan dan Perkembangan Vol. 1 No. 02, Juni 2018

Fawzani, Nurhidayati. (2018). Terapi Berhenti Merokok. Makara, kesehatan, vol. 9, no. 1, Juni 2015: $15-22$

Fawzani, N., \& Triratnawati, A. (2015). Terapi Berhenti Merokok. British Medical Journal, 9(1), 1522.

Fransiska, M., \& Firdaus, P. A. (2019). Faktor yang berhubungan dengan Perilaku Merokok pada Remaja Putra SMA X Kecamatan Payakumbuh. Jurnal Kesehatan, 10(1), 11. https://doi.org/10.35730/jk.v10i1 .367

Kemenkes, D. P. dan P. P. (2017). P2PTM_RAK2017.pdf (pp. 1-37). http://p2p.kemkes.go.id/wpcontent/uploads/2017/12/P2PTM_ RAK2017.pdf

Kemenkes RI. (2017). Pedoman Monitoring dan Evaluasi Pelaksanaan Program Indonesia Sehat dengan Pendekatan Keluarga (PIS-PK). Jakarta: Kementerian Kesehatan RI

Khairatunnisa. (2019). Hubungan Persepsi Tentang Kawasan Tanpa Rokok (KTR) Dengan Perilaku Merokok Pegawai Di Dinas Kesehatan Kota Tebing Tinggi. Jurnal JUMANTIK Vol. 4 No. 1 Des 2018 - Mei 2019

Larasati, Esti Rossa. (2018). Motivasi Berhenti Merokok pada Perokok Dewasa Muda Berdasarkan Transtheoretical Model (TTM). Jurnal Farmasi dan Ilmu Kefarmasian Indonesia Vol. 5 No. 2 Desember 2018

Moleong, L. J. (2018). Metodologi Penelitian Kualitatif. PT. Remaja Rosdakarya.

Nancy Hutabarat Tobing. (2018). Rokok dan Kesehatan Respirasi. SMF Paru RSUD Pasar Rebo, Jakarta

Oritasari. (2019). Strategi Mengatasi Kendala Berhenti Merokok Pada Klien Di Puskesmas Raman Utara Kabupaten Lampung Timur. Jurnal Dunia Kesmas Volume 8. Nomor 3. Juli 2019

Permenkes RI. (2017). PERATURAN MENTERI KESEHATAN REPUBLIK INDONESIA NOMOR 57 TAHUN 2017 TENTANG PERUBAHAN PENGGOLONGAN PSIKOTROPIKA. http://www.albayan.ae 
Prihatmono, Ignatius Gonggo dan Arifiyani, Lutfi Ayu. (2015). Upaya Berhenti Merokok Pada Perokok Wanita Di Klinik Berhenti Merokokdi Balai Pengobatan Penyakit Paru Paru (BP4) Yogyakarta. Vol X Nomor 4 Oktober 2015 - Jurnal Medika Respati

Priyoto. (2018). Teori Sikap dan Perilaku dalam Kesehatan. Nuha Medika.

Riskesdas. (2013). Penyajian PokokPokok Hasil Riset Kesehatan Dasar 2013.

Riskesdas, K. (2018). Hasil Utama Riset Kesehata Dasar (RISKESDAS). Journal of Physics A: Mathematical and Theoretical, 44(8), $1-200$. https://doi.org/10.1088/17518113/44/8/085201

Sadono, Delfi Novella. (2018). Proses Pemberdayaan Warga Kampung Tanpa Asap Rokok Di Kampung Bulaksari RT 7. Jurnal Promkes, Vol. 6, No. 1 Juli 2018: 35-45

Sari, Meta Juwita. (2019). Sikap Perokok Aktif Dalam Menanggapi Peringatan Bahaya Merokok Pada Iklan Rokok Di Televisi (Studi Masyarakat Desa Talang Jambu Kecamatan Kerkap Kabupaten Bengkulu Utara). Jurnal Professional FIS UNIVED Vol.6 No.1 Juni 2019

Setyawati, A. (2017). Alasan Berhenti Merokok Pada Wanita Mantan Pecantu Rokok Di Kota Madiun. Jurnal IImiah Kesehatan Keperawatan, 13(3), 119-124. https://doi.org/10.26753/jikk.v13 i3. 229

Sugiyono. (2016). Metode Penelitian Kuantitatif, Kualitatif dan R\&D. PT Alfabeta.

Sulastri. (2018). Keinginan Berhenti Merokok Pada Pelajar Perokok Berdasarkan Global Youth
Tobacco Survey di SMK Negeri Kota Padang. Jurnal Kesehatan Andalas. 2018; 7(2)

Susilowati, D. (2016). Promosi Kesehatan. 55.

Trisnowati, Heni dan Hardiyanti, Dwi Anggun. (2016). Klinik Konseling Berhenti Merokok Dan Kesehatan Kerja Pegawai (Studi Pada Puskesmas Jetis Yogyakarta). The 3rd Indonesian Conference on Tobacco oor Health, 26-30 November 2016

Umiyatun, Yuyun. (2019). Analisis Kebijakan dan Program Pencegahan Perilaku Merokok pada Sekolah Muhammadiyah di Kota Depok. Media Litbangkes, Vol. 29 No. 2, Juni 2019, 123 134

Wibowo, Marsiana. (2017). Perspektif Hambatan Terhadap Kemungkinan Remaja Berhenti Merokok. Unnes Journal of Public Health 6 (2) (2017)

Wulandari, Cicilia Ika dan Santoso, Agus. (2012). Pengalaman Menghentikan Kebiasaan Merokok Pada Mantan Perokok. Jurnal Nursing Studies, Volume 1, Nomor 1 Tahun 2012, Halaman $36-42$

Wulandari, Indhi April. (2019). Upaya Berhenti Merokok Pada Remaja Di Kecamatan Kepanjen Kabupaten Malang. Vol. 3 No. 5 Oktober 2019

Yugistyowati, Anafrin. (2018). Pengaruh Terapi Spiritual Emotional Freedom Technique (SEFT) Terhadap Motivasi Berhenti Merokok Pada Remaja. Jurnal Keperawatan Respati Yogyakarta, 5(Suppl 1), 2018, 34-38

Yusriani, Y., \& Indonesia, U. M. (2018). 20180527-yusrianipromkesdanpemberdayaan masy (Issue 